\title{
Aicardi-Goutières syndrome due to a paternal mosaic IFIH1 mutation
}

Victoria Tüngler, MD, MSc, Marion Doebler-Neumann, MD, Michaela Salandin, MD, Peter Kaufmann, MD, Christine Wolf, PhD, Nadja Lucas, PhD, Florian Harmuth, MSc, Jennifer Reichbauer, Ingeborg Krägeloh-Mann, MD, Rebecca Schüle, MD, and Min Ae Lee-Kirsch, MD

Neurol Genet 2020;6:e384. doi:10.1212/NXG.0000000000000384

Progressive immune-mediated neurodegeneration is a central feature of Aicardi-Goutières syndrome (AGS), a monogenic disorder characterized by chronic activation of antiviral type I interferon (IFN). ${ }^{1}$ Typically, AGS presents as subacute infancy-onset encephalopathy with microcephaly, leukodystrophy, and basal ganglia calcification, resulting in global developmental delay. AGS is either caused by loss-offunction mutations in TREX1, RNASEH2B, RNASEH2C, RNASEH2A, $S A M H D 1$, or $A D A R$, encoding genes involved in the metabolism of nucleic acids, or by gain-offunction mutations in IFIH1 encoding the cytosolic RNA sensor melanoma differentiationassociated protein 5 (MDA5). ${ }^{1}$ The phenotypic spectrum of IFIH1-associated mutations includes intracerebral vasculopathy, bilateral striatal necrosis, and isolated spastic paraparesis.

We report the rare case of AGS due to paternal mosaicism for an IFIH1 mutation in 2 brothers. The study was conducted with approval by the ethics committees of the University of Tübingen and Technische Universität Dresden, and written informed consent was obtained. Both siblings were born at term to healthy nonconsanguineous parents after uneventful pregnancies and with anthropometric birth data within normal limits. Their family history was unremarkable. After a period of normal development, both brothers presented with gait disturbances and progressive microcephaly. Bilateral lower limb spasticity manifested at the age of 18 months in the older brother (II:1) after he had learned to walk unsupported, whereas the younger brother (II:2) became symptomatic at the age of 12 months before learning to walk (figure, A). Apart from mild hypertonicity of the left arm and minor dysarthria in the older brother, neither of the 2 children showed signs of additional motor or cognitive deficits. Brain MRI revealed symmetric hyperintensities within the periventricular white matter in both brothers, with hypomyelination more pronounced in the older sibling (figure, B). Blood counts, inflammatory markers, and liver and renal function tests were unremarkable. Both siblings were clinically diagnosed with hereditary spastic paraplegia. Sequencing of 136 HSP-related genes (HaloPLEX hereditary spastic paraplegia Panel) identified a heterozygous variant of IFIH1 (NM_022168: c.2336 G>A, p. R779H) in both children. Of interest, the variant was also observed at low abundance in the blood-derived DNA sample of the clinically asymptomatic father. Sanger sequencing confirmed the heterozygous $\mathrm{R} 779 \mathrm{H}$ variant in both children, while a weak mutation peak was also observed in the sequence pherogram of the father, confirming that he was mosaic for R779H (figure, C). Thus, both children inherited the $\mathrm{R} 779 \mathrm{H}$ mutation through a germline mosaic from the father.

$\mathrm{R} 779 \mathrm{H}$ has previously been reported in at least 8 patients with AGS occurring either as a dominant mutation with reduced penetrance or as de novo mutation. ${ }^{2}$ We therefore investigated the family for signs of constitutive type I IFN activation in blood. Consistent with AGS, both brothers exhibited a strong IFN signature (IFN score 1,031.19 \pm 350.19 in I: 1 and $648.21 \pm 219.61$ in I:2, mean \pm SEM; normal range < 12.49). Although the mother showed no signs of IFN activation (IFN score 1.29), the father was also found to have an IFN signature (IFN score 404.04),

\author{
Correspondence \\ Dr. Lee-Kirsch \\ minae.lee-kirsch@ \\ uniklinikum-dresden.de
}

From the Department of Pediatrics (V.T., C.W., N.L., M.A.L.-K.), Medizinische Fakultät Carl Gustav Carus, Technische Universität Dresden; Department of Neuropediatrics (M.D.-N., I.K.M.), University of Tübingen, Germany; Child Neurology and Psychiatry Unit (M.S.), Paediatric Department, Bolzano Regional Hospital; Child Haematology and Oncology Unit (P.K.), Paediatric Department, Bolzano Regional Hospital, Italy; Institute of Medical Genetics and Applied Genomics (F.H.), University of Tübingen; and Center for Neurology and HertieInstitute for Clinical Brain Research (J.R., R.S.), University of Tübingen and German Center of Neurodegenerative Diseases, Germany.

Go to Neurology.org/NG for full disclosures. Funding information is provided at the end of the article.

The Article Processing Charge was funded by DFG.

This is an open access article distributed under the terms of the Creative Commons Attribution-NonCommercial-NoDerivatives License 4.0 (CC BY-NC-ND), which permits downloading and sharing the work provided it is properly cited. The work cannot be changed in any way or used commercially without permission from the journal. 
A



C

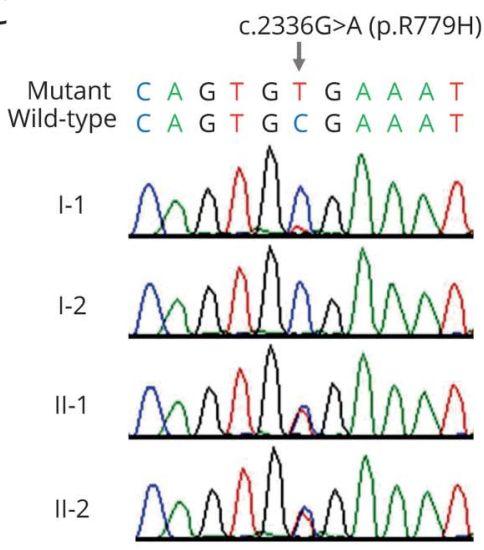

B

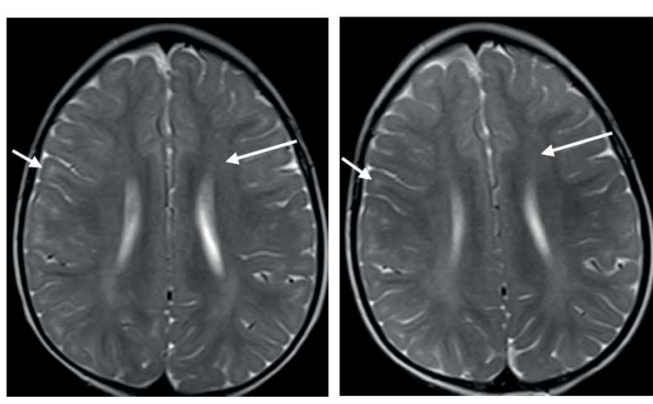

D

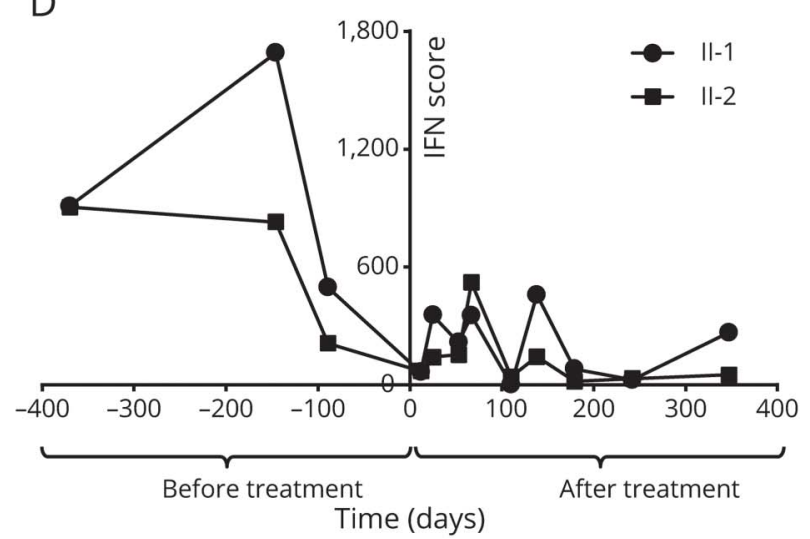

(A) Pedigree. (B) MRI of II:1 at 2 years, delayed myelination and white matter hyperintensity (left, white arrows), and unchanged at 5 years (right). (C) Heterozygous IFIH1 mutations in the children, weak mutation peak in the father (reverse sequence). (D) IFN scores ( $p \leq 0.0007$, before vs after ruxolitinib), calculated as described. ${ }^{3}$ IFN = interferon.

consistent with the mosaic state of the $\mathrm{R} 779 \mathrm{H}$ variant in his blood. Further examination of the father did not reveal microcephaly, vasculitis, or lupus-like symptoms. His blood counts and renal and liver function tests were unremarkable.

Uncontrolled activation of the MDA5 receptor because of activating IFIH1 mutations results in constitutive type I IFN signaling. ${ }^{2}$ Given the disease progression and lack of approved therapeutic options, we initiated off-label treatment with the Janus kinase (JAK) $1 / 2$ inhibitor ruxolitinib, which inhibits downstream signaling at the IFN- $\alpha / \beta$ receptor. Ruxolitinib started at 5 and 7 years, respectively, with a dose of $0.5 \mathrm{mg} / \mathrm{kg}$ was well tolerated without any hematologic or infectious adverse events. Ruxolitinib was increased to $0.75 \mathrm{mg} / \mathrm{kg}$ over time. Both children responded with a significant reduction of the IFN signature (figure, D). The parents reported a marked improvement in their childrens' quality of life during ruxolitinib treatment, who were described to be less fatigued and to engage more motivated in physical activities. Improved concentration of the older brother had a positive effect on academic achievements. Both children were able to maintain and even moderately improve their motor abilities, with a progress more noticeable in the younger brother, whose gait using orthoses improved by $40 \%$ after 8 months of treatment, as revealed by the dimension "walking, running, and jumping" of the Gross Motor Function Measure.
Clinical improvement observed in the patients supports previous reports, indicating that JAK inhibition may be therapeutically effective in type I IFN-driven disorders. ${ }^{3-7}$ Timely diagnosis is of clinical importance because early therapeutic intervention may modify the course of the disease and prevent further neurologic damage. Our findings also suggest that parental germline mosaicism may be more common than previously presumed in patients with AGS with apparent de novo IFIH1 mutation with significant implications for genetic counseling.

\section{Acknowledgment}

The authors are thankful to the family for participation in this study. The authors thank Diana Federl and Kerstin Engel for excellent technical assistance.

\section{Study funding}

Supported by grants from the Deutsche Forschungsgemeinschaft (LE1074/4-1 and grant 369799452/404459235 to ML-K and TU421/1-2 to VT), the NEUROMICS network (F5-2012-305121 to RS), Horizon 2020 'Solve-RD' (grant 779257 to RS), the National Institute of Health (NIH) (grant 5R01NS072248 to RS) and the Bundesministerium für Bildung und Forschung via funding for the TreatHSP consortium (01GM1905 to RS and MD-N). 


\section{Disclosure}

Disclosures available: Neurology.org/NG.

\section{Publication history}

Received by Neurology: Genetics June 7, 2019. Accepted in final form October 31, 2019.

\section{Appendix Authors}

\begin{tabular}{|c|c|c|c|}
\hline Name & Location & Role & Contribution \\
\hline $\begin{array}{l}\text { Victoria } \\
\text { Tüngler, } \\
\text { MD, MSc }\end{array}$ & $\begin{array}{l}\text { Technische } \\
\text { Universität } \\
\text { Dresden, } \\
\text { Germany }\end{array}$ & Author & $\begin{array}{l}\text { Study design, clinical } \\
\text { assessment, analysis, and } \\
\text { interpretation of the data, } \\
\text { and drafting of the } \\
\text { manuscript }\end{array}$ \\
\hline $\begin{array}{l}\text { Marion } \\
\text { Doebler- } \\
\text { Neumann, } \\
\text { MD }\end{array}$ & $\begin{array}{l}\text { University of } \\
\text { Tübingen, } \\
\text { Germany }\end{array}$ & Author & $\begin{array}{l}\text { Clinical assessment and } \\
\text { acquisition and analysis of } \\
\text { the data }\end{array}$ \\
\hline $\begin{array}{l}\text { Michaela } \\
\text { Salandin, } \\
\text { MD }\end{array}$ & $\begin{array}{l}\text { Regional } \\
\text { Hospital of } \\
\text { Bolzano, Italy }\end{array}$ & Author & $\begin{array}{l}\text { Clinical assessment and } \\
\text { acquisition of the data }\end{array}$ \\
\hline $\begin{array}{l}\text { Peter } \\
\text { Kaufmann, } \\
\text { MD }\end{array}$ & $\begin{array}{l}\text { Regional } \\
\text { Hospital of } \\
\text { Bolzano, Italy }\end{array}$ & Author & $\begin{array}{l}\text { Clinical assessment and } \\
\text { acquisition of the data }\end{array}$ \\
\hline $\begin{array}{l}\text { Christine } \\
\text { Wolf, PhD }\end{array}$ & $\begin{array}{l}\text { Technische } \\
\text { Universität } \\
\text { Dresden, } \\
\text { Germany }\end{array}$ & Author & $\begin{array}{l}\text { Acquisition and analysis of } \\
\text { the data }\end{array}$ \\
\hline $\begin{array}{l}\text { Nadja } \\
\text { Lucas, PhD }\end{array}$ & $\begin{array}{l}\text { Technische } \\
\text { Universität } \\
\text { Dresden, } \\
\text { Germany }\end{array}$ & Author & $\begin{array}{l}\text { Acquisition and analysis of } \\
\text { the data }\end{array}$ \\
\hline
\end{tabular}

Appendix (continued)

\begin{tabular}{|c|c|c|c|}
\hline Name & Location & Role & Contribution \\
\hline $\begin{array}{l}\text { Florian } \\
\text { Harmuth, } \\
\text { MSc }\end{array}$ & $\begin{array}{l}\text { University of } \\
\text { Tübingen, } \\
\text { Germany }\end{array}$ & Author & $\begin{array}{l}\text { Acquisition and analysis of } \\
\text { the data }\end{array}$ \\
\hline $\begin{array}{l}\text { Jennifer } \\
\text { Reichbauer }\end{array}$ & $\begin{array}{l}\text { University of } \\
\text { Tübingen, } \\
\text { Germany }\end{array}$ & Author & $\begin{array}{l}\text { Acquisition and analysis of } \\
\text { the data }\end{array}$ \\
\hline $\begin{array}{l}\text { Ingeborg } \\
\text { Krägeloh- } \\
\text { Mann, MD }\end{array}$ & $\begin{array}{l}\text { University of } \\
\text { Tübingen, } \\
\text { Germany }\end{array}$ & Author & $\begin{array}{l}\text { Clinical assessment, } \\
\text { analysis, and } \\
\text { interpretation of the data }\end{array}$ \\
\hline $\begin{array}{l}\text { Rebecca } \\
\text { Schüle, MD }\end{array}$ & $\begin{array}{l}\text { University of } \\
\text { Tübingen, } \\
\text { Germany }\end{array}$ & Author & $\begin{array}{l}\text { Study design and analysis } \\
\text { and interpretation of the } \\
\text { data }\end{array}$ \\
\hline $\begin{array}{l}\text { Min Ae Lee- } \\
\text { Kirsch, MD }\end{array}$ & $\begin{array}{l}\text { Technische } \\
\text { Universität } \\
\text { Dresden, } \\
\text { Germany }\end{array}$ & Author & $\begin{array}{l}\text { Study design, clinical } \\
\text { assessment, analysis, and } \\
\text { interpretation of the data, } \\
\text { and drafting of the } \\
\text { manuscript }\end{array}$ \\
\hline
\end{tabular}

\section{References}

1. Lee-Kirsch MA. The type I interferonopathies. Annu Rev Med 2017;68:297-315.

2. Rice GI, Del Toro Duany Y, Jenkinson EM, et al. Gain-of-function mutations in IFIH1 cause a spectrum of human disease phenotypes associated with upregulated type I interferon signaling. Nat Genet 2014;46:503-509.

3. König N, Fiehn C, Wolf C, et al. Familial chilblain lupus due to a gain-of-function mutation in STING. Ann Rheum Dis 2017;76:468-472.

4. Tüngler V, König N, Günther C, et al. Response to: "JAK inhibition in STINGassociated interferonopathy” by Crow et al. Ann Rheum Dis 2016;75:e76.

5. Kim H, Brooks KM, Tang CC, et al. Pharmacokinetics, pharmacodynamics, and proposed dosing of the oral JAK1 and JAK2 inhibitor baricitinib in pediatric and young adult CANDLE and SAVI patients. Clin Pharmacol Ther 2018;104:364-373.

6. Kothur K, Bandodkar S, Chu S, et al. An open-label trial of JAK 1/2 blockade in progressive IFIH1-associated neuroinflammation. Neurology 2018;90:289-291.

7. Zimmermann N, Wolf C, Schwenke R, et al. Assessment of clinical response to Janus kinase inhibition in patients with familial chilblain lupus and TREX1 mutation. JAMA Dermatol 2019;155:342-346. 


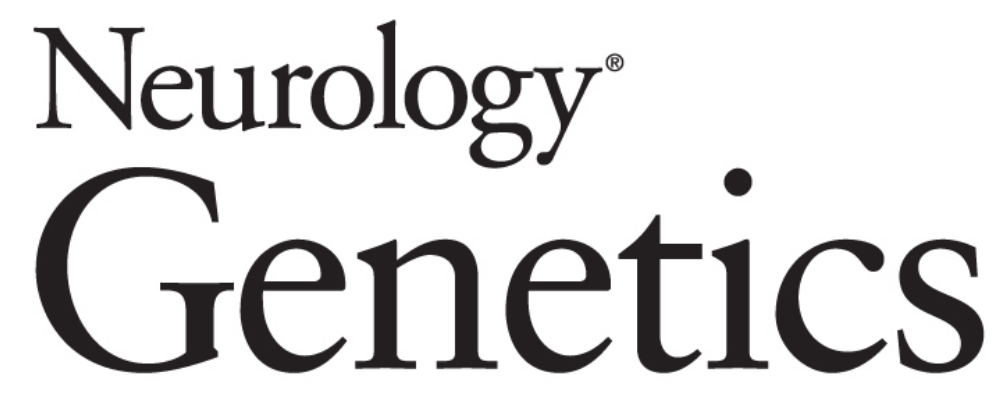

\section{Aicardi-Goutières syndrome due to a paternal mosaic IFIH1 mutation \\ Victoria Tüngler, Marion Doebler-Neumann, Michaela Salandin, et al. \\ Neurol Genet 2020;6; \\ DOI 10.1212/NXG.0000000000000384}

\section{This information is current as of December 19, 2019}

\section{Updated Information \& Services}

References

Subspecialty Collections

Permissions \& Licensing

Reprints including high resolution figures, can be found at: http://ng.neurology.org/content/6/1/e384.full.html

This article cites 7 articles, 2 of which you can access for free at: http://ng.neurology.org/content/6/1/e384.full.html\#\#ref-list-1

This article, along with others on similar topics, appears in the following collection(s):

All Clinical Neurology

http://ng.neurology.org//cgi/collection/all_clinical_neurology All Genetics

http://ng.neurology.org//cgi/collection/all_genetics

All Movement Disorders

http://ng.neurology.org//cgi/collection/all_movement_disorders All Pediatric

http://ng.neurology.org//cgi/collection/all_pediatric

Information about reproducing this article in parts (figures,tables) or in its entirety can be found online at:

http://ng.neurology.org/misc/about.xhtml\#permissions

Information about ordering reprints can be found online: http://ng.neurology.org/misc/addir.xhtml\#reprintsus

Neurol Genet is an official journal of the American Academy of Neurology. Published since April 2015, it is an open-access, online-only, continuous publication journal. Copyright Copyright $\left({ }^{\circ} 2019\right.$ The Author(s). Published by Wolters Kluwer Health, Inc. on behalf of the American Academy of Neurology.. All rights reserved. Online ISSN: 2376-7839.



